\title{
Physical protector in direct sowing of baru influencing in the initial growth of the seedlings
}

\author{
Rogério Costa da Silva ${ }^{1}$, Ana Paula Leite de Lima ${ }^{1}$, Sebastião Ferreira de Lima ${ }^{1}$, Guilherme \\ Marchesini Trevizani ${ }^{1}$, João Batista Leite Junior ${ }^{2}$ \\ ${ }^{1}$ Universidade Federal de Mato Grosso do Sul, Campus de Chapadão do Sul, Chapadão do Sul, Mato Grosso do Sul, Brasil. E-mail: \\ rogerio_costa92@hotmail.com, paula.leite@ufms.br, sebastiao.lima@ufms.br, guilhermetrevizani94@gmail.com \\ ${ }^{2}$ Universidade Federal de Goiás, campus Jataí, Jataí, Goiás, Brasil. E-mail: joaobleitejr@ufg.br
}

Received: 07/06/2018; Accepted: 17/08/2018.

\begin{abstract}
The objective of this study was to evaluate the influence of using physical protectors on the emergence and initial growth of Baru seedlings in a direct sowing system. The experiment was installed in a randomized complete block design, testing the use of physical protectors (no protection, P0; plastic cup $(500 \mathrm{~mL}$ ) without the bottom, P1; laminated wood, P2), with 12 repetitions. Weekly soil temperature monitoring was carried out in the morning and in the afternoon in the period between 14 and 56 days after sowing (DAS). Daily emergence follow-up was also performed, and the stem diameter, total height and number of leaves were measured at 81 DAS. The use of physical protectors in the direct seeding of Baru interfered in the soil surface temperature on the sowing point, on the seedling emergence speed index, seedling survival, stem diameter and seedling height. Implementing protectors slowed the seedling emergence speed, however it provided higher percentages of emergence, survival and greater growth in diameter and height.
\end{abstract}

Keywords: Dipteryx alata, forest implantation, native species.

\section{Protetor físico na semeadura direta de baru influenciando no crescimento inicial das mudas}

\section{RESUMO}

O objetivo do trabalho foi avaliar a influência do uso de protetores físicos sobre a emergência e o crescimento inicial de mudas de baru em sistema de semeadura direta. $\mathrm{O}$ experimento foi instalado em delineamento em blocos casualizados, testando uso de protetor físico (sem protetor, P0; copo plástico (500 mL), sem o fundo, P1; laminado de madeira, P2), com 12 repetições. No período entre 14 e 56 dias após semeadura (DAS), foi feito o acompanhamento semanal da temperatura do solo, pela manhã e à tarde. Foi realizado, ainda, o acompanhamento diário da emergência e, 81 DAS, foram mensurados o diâmetro do colo, a altura total e o número de folhas. O uso de protetores físicos em semeadura direta de baru interferiu na temperatura superficial do solo sobre o ponto de semeadura, no índice de velocidade de emergência das plântulas, na sobrevivência de plântulas, no diâmetro do colo e na altura das mudas. $\mathrm{O}$ uso de protetores tornou mais lenta a velocidade de emergência de plântulas, porém propiciou maior porcentagem de emergência, de sobrevivência e maior crescimento em diâmetro e altura.

Palavras-chave: Dipteryx alata, implantação florestal, espécie nativa. 


\section{Introduction}

Dipteryx alata (known as Baru, Cumbaru or Cumaru), belong to the Fabaceae family and is a native species of wide occurrence in the cerrado biome (Lorenzi, 1992). This species has great potential for exploitation due to both the possibility of harmonious coexistence of Baru plants with other anthropic activities, especially in areas where subsistence or family farming is developed, and as a consequence of its multiple uses. It has good adaptation to different types of soils, rusticity, possibility of consortium with pastures and good potential for use of the wood, leaves and fruits. It is a species that presents potential for cultivation in plantations, especially due to the functional characteristics of its almond (Sano et al., 2004; Vera and Souza, 2009; Vera et al., 2009; Magalhães, 2014).

In Brazil, the most adopted method for implanting forest stands has been the use of seedlings produced in nurseries (Finger et al., 2003; Silva and Carvalho, 2008). Seedlings are formed under controlled conditions in this system during a period of time that varies with the species.

When compared to exotic species such as eucalyptus which is traditionally used for implanting forests, the seedling production of native species demands longer permanence time in the nursery due to the slow growth many of them present (Cunha et al., 2005) which often discourages and increases its production costs (FloresAylas et al., 2003).

According to Finger et al. (2003), the production or even the acquisition of seedlings for planting generally represents a significant cost component of implanting a forest. Thus, there is a need to seek alternative techniques that minimize the implantation costs, either for the recovery of degraded ecosystems (Mattei and Rosenthal, 2002; Ferreira et al., 2007; Santos et al., 2012) or for implantation of production forests (Schneider et al., 1999; Finger et al., 2003). In this context, direct seeding has been adopted in Brazil as a technique for planting and alternative forest restoration, since it enables reducing costs, mainly in labor and seedling production (Silva and Carvalho, 2008; Soares and Rodrigues, 2008; Santos et al., 2012).

Adoption of any planting system has positive and negative points. When comparing direct sowing with seedling planting, sowing presents a greater risk of obtaining low seedling germination and survival rates (Santos et al., 2012). In working with direct sowing of Pinus taeda, Mattei (1995) reports that the critical period of seed loss starts from sowing up to the end of the germination period, and that losses are still significant during the initial plant development period.

Among limiting agents in the direct sowing system are the factors inherent to the environment, which influence germination such as light, temperature, water, growth medium, fauna and microorganisms (Floriano, 2004). Thus, prior knowledge of these factors allows us to control and optimize the germination quality, speed and uniformity. As a way to enable rapid germination, Mattei and Rosenthal (2002) claim that a favorable microenvironment to germination and seedling establishment must be created in the field.

Physical protectors such as wood laminates or bottomless plastic cups have been used over the sowing point to minimize the negative effects of the environment. Mattei (1995) found that the use of a protector in direct Pinus taeda sowing provided efficient seed protection against burial of these plants during heavy rains and animal attacks. Similarly, Mattei and Rosenthal (2002) recommended the use of protectors for Peltophorum dubium, as they provided an increase in the emergence and establishment of seedlings in the field. However, Ferreira et al. (2007) found no benefits for the Trema micrantha, Senna multijuga, S. macranthera and Solanum granulosoleprosum species, neither for the seedling emergence or survival; however, its use promoted higher height and stem diameter in S. multijuga, and greater height in $S$. macranthera at three months of age.

Although there are studies that prove the efficiency of physical protectors for implanting stands for some native tree species, it is also necessary to develop studies that prove its effectiveness for many other native species of economic and environmental interest, since each species has an intrinsic behavior regarding the requirements for each phase of its development.

Thus, the objective of this study was to evaluate the use of physical protectors in the germination and early development of Dipteryx alata seedlings, in a direct sowing field system.

\section{Material and Methods}

This experiment was carried out in Chapadão do Sul, MS (18 $41^{\prime} 33^{\prime \prime} \mathrm{S}$ and $\left.52^{\circ} 40^{\prime} 45^{\prime \prime} \mathrm{W}\right)$ at an average altitude of $790 \mathrm{~m}$, in the experimental area of the Federal University of Mato Grosso do Sul (UFMS). The original vegetation cover of the municipality is of cerrado and grasslands (campos limpos), and the predominant soil class is Dystrophic Red Latosol. According to the Köppen classification, the climate is tropical humid (Aw), with rainy season in the summer and dry season in the winter, and the average annual precipitation is of $1,850 \mathrm{~mm}$. The average annual temperature of the region varies from $13^{\circ} \mathrm{C}$ to $28^{\circ} \mathrm{C}$ (Cunha et al., 2013).

The experimental design was randomized blocks testing the use of physical protectors (no protector, $\mathrm{P} 0$; bottomless plastic cup $(500 \mathrm{~mL}), \mathrm{P} 1$; laminated wood $(10.0 \mathrm{~cm} \times 28.3 \mathrm{~cm})$ forming a circular section, $\mathrm{P} 2)$, 
with twelve replicates. Each plot consisted of four sowing pits with one Baru seed in each.

The fruits were harvested in October 2015, from matrix trees located in the rural area of Chapadão do Sul, MS, manually stripped for exposure of the endocarp and then dried in the open air.

For implantation of the experiment, the soil was plotted and the points were marked following a $1.0 \times 1.0$ $\mathrm{m}$ spacing between pits. Manual sowing was performed in February 2016, at a depth of $3.0 \mathrm{~cm}$ using the seed enveloped by the endocarp of the fruit. After sowing, the physical protectors were placed over the seeded sites with their bases (approximately $2 \mathrm{~cm}$ ) buried in the ground for better attachment of the protectors. Weed control was performed during the experiment through manual weeding in the total area of the experiment.

Daily monitoring of seedling emergence started at 26 days after sowing (DAS) and continued until 41 DAS. Pits without seedling emergence were considered as non-germinated.

From 14 to 56 DAS, the soil temperature was measured at the sowing point using a Digital Infrared Laser Thermometer (GM-300). This evaluation was carried out weekly in the morning (9:00 a.m.) and in the afternoon (15:00 a.m.). The temperature in the pits with a physical protector was obtained in the central region of the microenvironment formed by them, while the temperature in pits without protection was measured at the sowing point, duly marked by a wooden stake.

The physical protectors were removed at 81 DAS and the parameters of total height $(\mathrm{Ht})$ and stem diameter (SD) were measured using a graduated ruler and digital caliper, respectively, and the number of leaves $(\mathrm{Nl})$.

Based on the emergence data, the number of emerged seedlings was counted at 41 DAS, when no more emergence was found. The number of established plants at the end of the evaluation (81 DAS) was also recorded. The emergence percentage and survival rates were then calculated from the obtained data. The Emergence Speed Index (ESI), was also calculated as proposed by Maguire (1962): ESI = $\mathrm{N} 1 / \mathrm{DQ}+\mathrm{N} 2 / \mathrm{D} 2+\ldots+\mathrm{Nn} / \mathrm{Dn}$, where: $\mathrm{ESI}=$ Emergence Speed Index; $N=$ number of seedlings verified on the day of the count; $\mathrm{D}=$ number of days after sowing at which the count was performed.

The data were submitted to analysis of variance and the means were compared by the Tukey test at $5 \%$ probability.

\section{Results and Discussion}

The biometric parameters evaluated were influenced by the use of a physical protector at the sowing point, except for the number of leaves and the emergence rate (Table 1).

The temperature on the soil surface in both the morning and in the afternoon reached higher values when no physical protector was used on the sowing point throughout the evaluated period. Lower temperatures were generally observed when the wood laminate was used as a protector (Table 2). According to Silva et al. (2006), the soil surface temperature is an important parameter to be considered in the direct sowing of forest species, as it directly affects plant growth.

When no physical protector (P0) was used in the morning, the temperature measured at the soil surface ranged from $24.5^{\circ} \mathrm{C}$ (35 DAS) to $41.4^{\circ} \mathrm{C}$ (28 DAS) (Table 2). While this variation in the afternoon was from $27.0^{\circ} \mathrm{C}$ (21 DAS) to $41.3^{\circ} \mathrm{C}$ (42 DAS). For the plastic protector $(\mathrm{P} 1)$, the variation was from $24.3^{\circ} \mathrm{C}$ to $39.9^{\circ} \mathrm{C}$ in the morning, and from $27.3^{\circ} \mathrm{C}$ to $37.6^{\circ} \mathrm{C}$ in the afternoon. Using the wood laminate (P2) as protector, the temperature reached at the soil surface varied less in relation to the others, from $19.0^{\circ} \mathrm{C}$ to $33.0^{\circ} \mathrm{C}$ in the morning and from $24.7^{\circ} \mathrm{C}$ to $33.1^{\circ} \mathrm{C}$ in the afternoon. The observed values represent a mean variation range from $15.5^{\circ} \mathrm{C}, 12.9^{\circ} \mathrm{C}$ and $11.2^{\circ} \mathrm{C}$ for $\mathrm{P} 0, \mathrm{P} 1$ and $\mathrm{P} 2$, respectively. This shows that the smallest amplitudes of variation occurred when protectors were used over the sowing point, and the lowest variation between the two tested protectors was observed for the wood laminate.

According to Moreschi (2012), wood presents low thermal conductivity, assuming great importance for obtaining temperature insulation, and the heat irradiation in this material is very low compared to other materials due to such low conductivity, moderate basic densities and the specific heat of the wood.

The use of a physical protector influenced the Emergence Speed Index (ESI), slowing the emergence of Baru seedlings (Figure 1). One of the factors that may have influenced this result is the interference that the physical protector exerted on the temperature of the surface layer of the soil (Table 2).

Temperature is a factor of great importance in seed germination (Finger et al., 2003; Malavasi et al., 2010). According to Brancalion et al. (2010), the optimal range for seed germination of most Brazilian tree species is between $25^{\circ} \mathrm{C}$ and $30^{\circ} \mathrm{C}$. The mean soil temperature recorded in the microenvironment of the wood laminate in both the morning and in the afternoon for all evaluated ages remained lower than the others (Table 2 ), and at 21, 35 and 56 DAS the means remained below $25^{\circ} \mathrm{C}$, which may have interfered in the ESI result of this treatment. 
Table 1. ANOVA for total height, stem diameter, number of leaves and emergence speed index. Chapadão do Sul, MS, 2016.

\begin{tabular}{llllll}
\hline \multicolumn{5}{c}{ Mean square } \\
\hline Variation source & GL & Total height & Stem diameter & Number of leaves & ESI \\
\hline Block & 11 & 4.80 & 0.00096 & 0.15 & 0.00028 \\
Protectors & 2 & $44.64^{* *}$ & $0.00605^{*}$ & $0.50^{\text {ns }}$ & $0.07328^{* *}$ \\
Residue & 22 & 4.70 & 0.00121 & 0.17 & 0.00015 \\
\hline Total & 35 & & & & 7.18 \\
\hline CV $(\%)$ & & 10.33 & 6.20 & 9.30 & 0.17 \\
Mean & 20.99 & 0.56 & 4.42 &
\end{tabular}

**significant at $1 \%$ probability; *significant at $5 \%$ probability by the Tukey test; ESI = emergence speed index, CV $(\%)=$ coefficient of variation

Table 2. Average temperature $\left({ }^{\circ} \mathrm{C}\right)$ observed on the soil surface in the morning and afternoon with the use of physical protectors at the sowing point up to 56 days after planting. Chapadão do Sul, MS, 2016.

\begin{tabular}{|c|c|c|c|c|c|c|c|}
\hline \multirow{2}{*}{ Protector } & \multicolumn{7}{|c|}{ Temperature $\left({ }^{\circ} \mathrm{C}\right)$} \\
\hline & 14 DAS & $21 \mathrm{DAS}$ & $28 \mathrm{DAS}$ & 35 DAS & 42 DAS & 49 DAS & $56 \mathrm{DAS}$ \\
\hline & Morning & & & & & & \\
\hline P0 & $29.8 \mathrm{aC}$ & $24.5 \mathrm{aD}$ & $41.4 \mathrm{aA}$ & $24.5 \mathrm{aD}$ & 35.0 a B & $29.2 \mathrm{a} \mathrm{C}$ & $26.1 \mathrm{a} \mathrm{D}$ \\
\hline $\mathrm{P} 1$ & $28.5 \mathrm{abC}$ & $24.3 \mathrm{aD}$ & $39.9 \mathrm{aA}$ & $24.3 \mathrm{aD}$ & $32.2 \mathrm{~b} \mathrm{~B}$ & 28.6 a C & $24.4 \mathrm{~b} \mathrm{D}$ \\
\hline \multirow[t]{2}{*}{$\mathrm{P} 2$} & $28.1 \mathrm{bB}$ & $22.4 \mathrm{bD}$ & $33.0 \mathrm{bA}$ & $22.7 \mathrm{bD}$ & $26.1 \mathrm{c} \mathrm{BC}$ & $25.7 \mathrm{~b} \mathrm{C}$ & $19.0 \mathrm{c} \mathrm{E}$ \\
\hline & Afternoor & & & & & & \\
\hline P0 & $34.3 \mathrm{aC}$ & $27.0 \mathrm{aF}$ & $28.9 \mathrm{aE}$ & $29.2 \mathrm{aE}$ & $41.3 \mathrm{aA}$ & 31.0 a D & $36.9 \mathrm{aB}$ \\
\hline P1 & $33.9 \mathrm{aB}$ & $27.3 \mathrm{aE}$ & $29.1 \mathrm{aD}$ & $28.8 \mathrm{aDE}$ & $37.6 \mathrm{bA}$ & 31.6 a C & $33.0 \mathrm{bBC}$ \\
\hline $\mathrm{P} 2$ & $33.1 \mathrm{aA}$ & $24.7 \mathrm{bG}$ & $26.9 \mathrm{bEF}$ & $26.1 \mathrm{bFG}$ & $30.5 \mathrm{cB}$ & $28.4 \mathrm{bCD}$ & $29.2 \mathrm{cBC}$ \\
\hline
\end{tabular}

P0: Sowing without physical protector; P1: seeding with plastic cup; P2: seeding with wood laminate. Means followed by the same lowercase letter in the column and uppercase in the row do not differ by Tukey test at $5 \%$ probability.

Comparing the mean temperatures reached at the soil surface when the physical protector (P0) was not used and when the plastic protector (P1) was used (Table 2), it can be seen that no significant statistical difference was observed for most evaluations in both the morning and in the afternoon between these two treatments. This indicates that there may be interference of factors other than temperature in the emergence speed of Baru seedlings, since there was no significant difference between ESI observed between P1 and P2 protectors (Figure 1).

Although the ESI of the seedlings that did not receive physical protection (P0) was statistically superior to those in which the protector (P1 and P2) was used (Figure 1), it can be observed that there was no significant variation between the treatments tested when analyzing the emergence percentage for the three treatments (Figure 2) at 41 days after sowing, where P0 and $\mathrm{P} 2$ reached $98 \%$ of emerged seedlings, while P1 reached $96 \%$. Similarly, Ferreira et al. (2007) verified that the use of the physical protector did not benefit the emergence percentage of any of the studied species (Trema micrantha, Senna multijuga, S. macranthera and Solanum granuloso-leprosum).

In analyzing the survival percentage of emerged seedlings at 81 DAS (Figure 3), it was observed that the use of physical protectors (P1 and P2) increased seedling survival rate $(98 \%)$ compared to the result achieved by P0 (83\%). Mattei and Rosenthal (2002) recommended the use of physical protectors for Peltophorum dubium because they provided an increase in the emergence and establishment of seedlings in the field. 


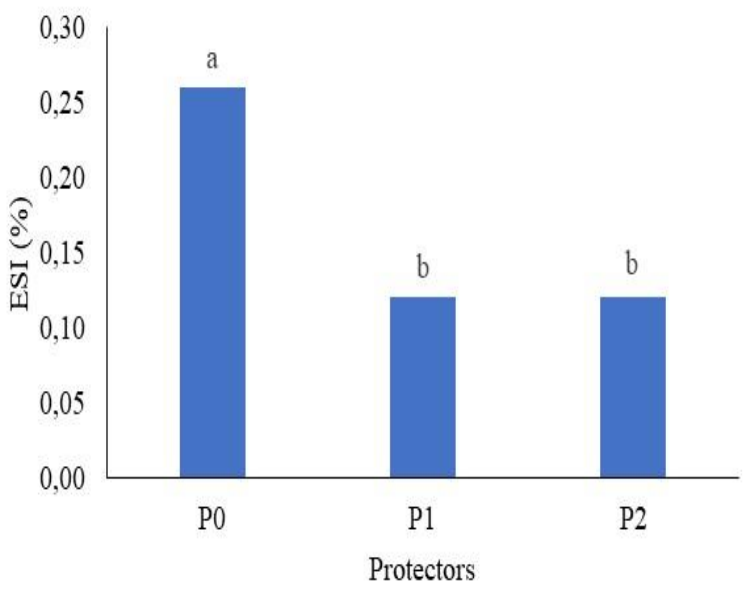

Figure 1. Emergence Speed Index (ESI) of Baru seedlings due to the use of physical protectors. (Means followed by the same letter do not differ from each other by the Tukey test at $1 \%$ of probability).

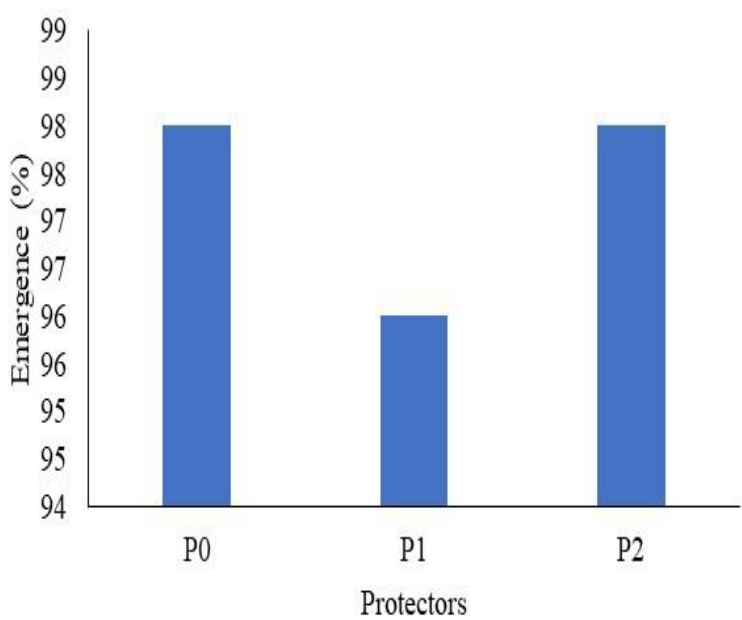

Figure 2. Percentage of emergence (E\%) of Baru seedlings, at 41 days after sowing, due to the use of physical protectors, in Chapadão do Sul, MS.

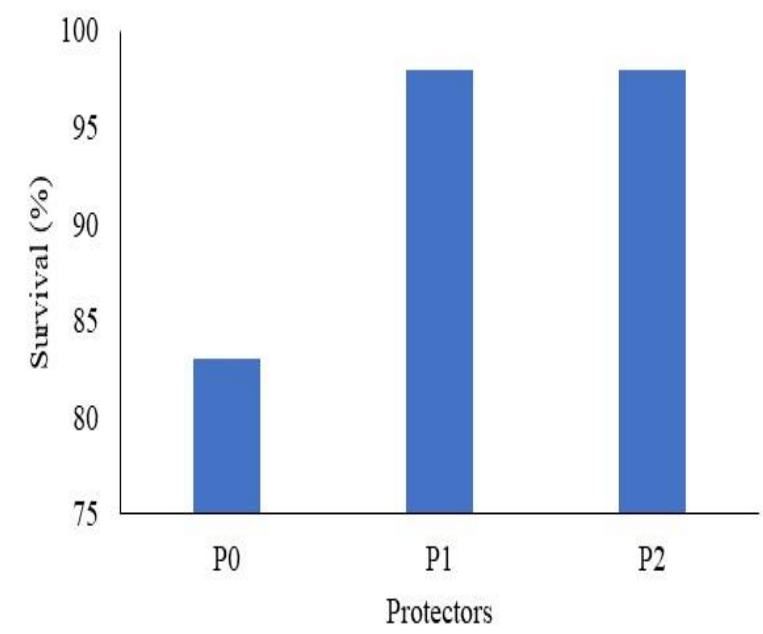

Figure 3. Survival of emerged Baru seedlings from to the 81 DAS due to the use of physical protectors in Chapadão do Sul, MS.
According to Mattei (1995) and Mattei and Rosenthal (2002), the natural control of predators without the need for applying chemical pesticides, shelter against burial and tipping as a consequence of surface runoff, and lower carrying of seeds and seedlings during periods of heavy rains are among the benefits of using seed protectors. The occurrence of surface runoff after rains was observed during the experiment, which may have interfered in this result. In testing the use of a physical protector in the direct sowing of Pinus taeda, Mattei (1995) concluded that its use in the planting points provided efficient seed protection against their burial in the event of heavy rains.

In analyzing the biometric parameters of Baru seedlings at 81 DAS (Table 3), it can be observed that the use of the physical protector positively interfered in stem diameter and total height of the seedlings. However, no significant difference was observed for the number of leaves.

Table 3. Height, diameter and number of leaves of baru seedlings due to the use of physical protectors at 81 days after sowing.

\begin{tabular}{cccr}
\hline Protector & $\begin{array}{c}\text { Height } \\
(\mathrm{cm})\end{array}$ & $\begin{array}{c}\text { Diameter } \\
(\mathrm{cm})\end{array}$ & $\begin{array}{c}\text { Number of } \\
\text { leaves }\end{array}$ \\
\hline P0 & $19.01 \mathrm{~b}$ & $0.53 \mathrm{~b}$ & $4.60 \mathrm{a}$ \\
P1 & $21.08 \mathrm{ab}$ & $0.58 \mathrm{a}$ & $4.46 \mathrm{a}$ \\
P2 & $22.87 \mathrm{a}$ & $0.57 \mathrm{ab}$ & $4.19 \mathrm{a}$ \\
\hline
\end{tabular}

P0: Sowing without physical protector; P1: seeding with plastic cup; P2: = seeding with wood laminates. Means followed by the same lowercase letter in the column do not differ by Tukey test at $5 \%$ probability.

No significant difference was observed between the plastic and laminate protectors for the seedlings' height; however, wood laminates provided higher average height when compared to seedlings that did not receive a physical protector (Table 2). Regarding the stem diameter variable, no significant differences were observed between the two protectors (P1 and P2); however, in contrast to the seedling height, the largest average diameter was verified for the plastic protector (P1) when compared to the diameter achieved by the seedlings that did not receive a protector (Table 3 ). In working with tree species for the recovery of forest ecosystems, Ferreira et al. (2007) found better performance in both diameter and height for Senna multijuga when using a physical protector. Similarily, in working with direct sowing in the recovery of degraded areas, Malavasi et al. (2010) verified the positive effect of a physical protector (PET bottle) on height and diameter on the development of Peltophorum dubium and Enterolobium contortisiliquum species at 90 DAS. 


\section{Conclusions}

The use of physical protectors in direct seeding of Baru (Dipteryx alata) interferes in the surface temperature of the soil on the sowing point, on the seedling emergence speed index and survival, and on stem diameter and height of seedlings.

The use of protectors slowed the seedling emergence speed, but provided a higher emergence percentage, survival rate and greater growth in diameter and height.

\section{Bibliographic References}

Brancalion, P.H.S., Novenbre, A.D.L.C., Rodrigues, R.R., 2010. Temperatura ótima de germinação de sementes de espécies arbóreas brasileiras. Revista Brasileira de Sementes, 32, 015-021.

Cunha, A.O., Andrade, L.A., Bruno, R.L.A., Silva, J.A.L., Souza, V.C., 2005. Efeitos de substratos e das dimensões dos recipientes na qualidade das mudas de Tabebuia impetiginosa (Mart. Ex. D.C.) Standl. Revista Árvore, 29, 507-516.

Cunha, F.F, Magalhães, F.F., Castros, M.A., 2013. Métodos para estimativa da evapotranspiração de referência para Chapadão do Sul - MS. Engenharia na Agricultura, 21, 159-172.

Ferreira, R.A., Davide, A.C., Bearzoti, E., Motta, M.S., 2007. Semeadura direta com espécies arbóreas para recuperação de ecossistemas floretais. Cerne, 13, 271-279.

Finger, C.A.G., Schneider, P.R., Garlet, A., Eleotério, J.R., Berger, R. 2003. Estabelecimento de povoamentos de Pinus elliottii Engelm pela semeadura direta a campo. Ciência Florestal, 13, 107-113.

Flores-Aylas, W.W., Saggin-Júnior, O.J. Siqueira, J.O.; Davide, A.C., 2003. Efeito de Glomus etunicatum e fósforo no crescimento inicial de espécies arbóreas em semeadura direta. Pesquisa Agropecuária Brasileira, 38, 257-266.

Floriano, E.P., 2004. Germinação e dormência de sementes florestais, Santa Rosa, ANORGS.

Lorenzi, H., 1992. Árvores brasileiras: manual de identificação e cultivo de plantas arbóreas do Brasil, Nova Odessa, Instituto Plantarum.

Magalhães, R.M.A., 2014. A cadeia produtiva da amêndoa do baru (Dipteryx alata Vog) no cerrado: análise da sustentabilidade da sua exploração. Ciência Florestal, 24, 665676.
Maguire, J.D., 1962. Speed germination-aid in selection and evaluation for seedling emergence and vigor. Crop Science, 2, 176-177.

Malavasi, U.C., Klein, J., Malavasi, M.M., 2010. Efeito de um protetor físico na semeadura direta de duas espécies florestais em área de domínio ciliar. Revista Árvore, 34, 781-787.

Mattei V.L., 1995. Agentes limitantes à implantação de Pinus taeda L. por semeadura direta. Ciência Florestal, 5, 9-8.

Mattei, V.L., Rosenthal, M.D.A. 2002. Semeadura direta de canafístula (Peltophorum dubium (Spreng) Taub no enriquecimento de capoeiras. Revista Árvore, 26, 649-654.

Moreschi, J.C., 2012. Propriedades da madeira, Universidade Federal do Paraná, Curitiba.

Sano, S.M., Ribeiro, J.F., Brito, M.A., 2004. Baru: biologia e uso, Embrapa Cerrados, Brasília.

Santos, P.L., Ferreira, R.A., Aragão, A.G., Amaral, L.A., Oliveira, A.S., 2012. Estabelecimento de espécies florestais nativas por meio de semeadura direta para recuperação de áreas degradadas. Revista Árvore, 36, 237-245.

Schneider, P.R., Finger, C.A.G., Schneider, P.S.P., 1999. Implantação de povoamento de Dodonaea viscose (L.) Jacq com mudas e semeadura direta. Ciência Florestal, 9, 29-33.

Silva, V.R., Reichert, J.M., Reinert, D.J., 2006. Variação na temperatura do solo em três sistemas de manejo na cultura do feijão. Revista Brasileira de Ciência do Solo, 30, 391-399.

Silva, B.M., Carvalho, N.M., 2008. Efeito do estresse hídrico sobre o desempenho germinativo da semente de faveira (Clitoria fairchildiana R.A. Howard - Fabaceae) de diferentes tamanhos. Revista Brasileira de Sementes, 30, 55-65.

Soares, P.G., Rodrigues, R.R., 2008. Semeadura direta de leguminosas florestais: efeito da inoculação com rizóbio na emergência de plântulas e crescimento inicial no campo. Ciência Florestal, 36, 155-121.

Vera, R., Soares Junior, M.S., Naves, R.V., Souza, E.R.B., Fernandes, E.P., Caliari, M., Leandro, W.M., 2009. Características químicas de amêndoas de barueiros (Dipteryx alata Vog.) de ocorrência natural no cerrado do estado de Goiás. Revista Brasileira de Fruticultura, 31, 112-118.

Vera, R., Souza, E.R.B., 2009. Baru. Revista Brasileira de Fruticultura, 31, 01 